\title{
Reading Habits among Student Teachers In Relation To Their Age, Gender and Management
}

\author{
Dr. M. Ravi Babu ${ }^{1}$, Poosapati Durgaiah ${ }^{2}$
}

\section{ABSTRACT}

A good reading habit is necessary for a healthy intellectual growth and plays a very crucial role in enabling a person to achieve practical efficiency. Reading Habits means behavior which express the lightness of reading of individual, which occur regularly of leisure reading approach, type of reading tastes of reading \& use of library services. Reading habit is an active skill based process of constructing meaning and gaining knowledge from oral, visual and written text. The present study was conducted on 600 student teachers from Hyderabad and Ranga Reddy districts of Telangana State. The result reveals that there was a significant difference in reading habits in relation to their age, gender and management among student teachers.

Keywords: Reading Habits, Gender, Management.

Reading is one of the three ' $r$ ' with which a child starts his education. In fact the success and failure of his academic life depends to a large extent upon his reading ability. Reading may be regarded as a basic skill to be acquired by every learner and hence every effort should be directed towards its development in children from early life. Studies have shown that schools and teachers do not have as big an influence on children as parents \& friends do. The people that children spend the most time with are the ones who govern their thoughts and directions in life. To be around people who propagate learning and reading is always a good thing for a child. There are many benefits to picking up such reading habits, especially when it comes to matters that pertain to the child's mental growth. Without a reading habit, a child can grow up with some difficulties, especially if in a line of work that requires reading at any level.

Reading occupies a pivotal role in the life of a man. Reading opens the doors of the treasures of knowledge. It is an important means of introducing the child to the world that surrounds him. It is the very foundation on which the edifice of the child is $t$ o be built. Reading is one of the most

\footnotetext{
${ }^{1}$ M.A (Psy), M.Ed., Ph.D Trained Graduate Teacher, Telangana State Model School, India

${ }^{2}$ Ph.D Research Scholar, Faculty of Education, Osmania University, Hyderabad, India

*Responding Author

(C) 2016, R Babu, P Durgaiah; licensee IJIP. This is an Open Access Research distributed under the terms of the Creative Commons Attribution License (http://creativecommons.org/licenses/by/2.0), which permits unrestricted use, distribution, and reproduction in any Medium, provided the original work is properly cited.
} 


\section{Reading Habits among Student Teachers In Relation To Their Age, Gender and Management}

important components of our language and it is an essential tool for lifelong learning for all learners. In order to face the 21st century, education has to prepare these learners to adapt to social and technological changes that are taking place at an unprecedented rate. Education under these circumstances depends largely on language competency. In this context, reading especially is a resource for continued education, for the acquisition of new knowledge and skills, for gaining information through media, especially newspapers, books, radio, television, and the computers. Reading habits are the intellectual activities for giving more information, knowledge and learn to various types of things and their activities. Reading Habits means behavior which express the lightness of reading of individual, which occur regularly of leisure reading approach, type of reading tastes of reading \& use of library services. Reading habit is an active skill based process of constructing meaning and gaining knowledge from oral, visual and written text. A good reading habit is necessary for a healthy intellectual growth and plays a very crucial role in enabling a person to achieve practical efficiency. Furthermore, an individual's interests are determined to a considerable extent by the amount he will read and the intensity with which he will pursue his reading activity. By reading books, one gets confirmation or rejection of one's own ideas, which makes one think more critically about right and wrong in the society. Reading provides people with a sense of values, which enable them gradually to develop the greatest of all virtues, that is the ability to understand rather than condemn. Books can also be very comforting, especially at times when one doubts one's self and one's beliefs. Pleasure reading furthers the development of reading as life-long habit which strengthens both language skills and fluency noted that children improve their reading skill when they read for pleasure. Cunningham and Stanovich (1998) reported that reading volume both inside and outside the school has a significant impact on the development of reading speed and fluency, vocabulary, general knowledge overall verbal ability and academic achievements.

\section{Factors Influencing Reading Habits}

It is difficult to single out a primary factor leading to the establishment of one's attitude toward reading, but environment, particularly the home, probably provides the greatest influence. Teachers influence students, they have the potential for influencing students' attitudes toward reading. Environment at School / College / Home / Society plays an important role in influencing reading habits.

The reading habits of children have long been a matter of much interest to educators, parents, librarians, publishers and other stake holders. An understanding of reading habits and preferences of children would help them to take necessary measures for promoting reading among children. It is widely acknowledged that life-long habit of reading can best be inculcated and nurtured at the early stage. It is however a general observation that there is over emphasis on study reading rather than recreational or voluntary reading among children. Cheah (1998) noted that while students in Singapore will not hesitate to read school related materials, getting them to become life-long readers and read for the pleasure remains an uphill task. There are many factors

(C) The International Journal of Indian Psychology, ISSN 2348-5396 (e)| ISSN: 2349-3429 (p) | 171 


\section{Reading Habits among Student Teachers In Relation To Their Age, Gender and Management}

that motivate reading among children. An international survey has shown that nearly half of the UK students participating in the study said that they read for relaxation while majority of the children from twelve developing countries revealed that they read for passing examinations (Books Aid International 2003). A study of young people in Britain aged between 11 and 18 years found that peer influence was the top most reason for reading books (Market \& Opinion International MORI, 2004). A survey of 431 pre kindergarten through grade eight students in the United States found that $71 \%$ of the students who perceived themselves as good readers had a positive attitude towards reading while none of the students who regarded themselves as poor readers enjoyed reading (Cosgrove, 2001).

\section{Objectives}

1. To find the reading habits among student teachers in relation to their age.

2. To find the reading habits among student teachers in relation to their gender.

3. To find the reading habits among student teachers in relation to their management.

\section{Hypothesis}

1. There will be no significant difference between reading habits among student teachers in relation to their age.

2. There will be no significant difference between reading habits among student teachers in relation to their gender.

3. There will be no significant difference between reading habits among student teachers in relation to their management.

\section{Sample of the Study}

The sample consisted of 600 student teachers (pursuing B.Ed Two Years course) from Hyderabad and Ranga Reddy districts of Telangana State, India

\section{Tool of the Study}

Reading Habits Tool was prepared by the researcher. The tool consisted of 54 statements with five options for each statement. The options were Never, Rarely, Sometimes, Very often and Always. The student teacher had to mark his / her response in any one of the options stated as per his / her reading interest. The score allotted to the responses were 1,2,3,4 and 5.

\section{Reliability and Validity}

Test-retest method was used to establish the reliability of the Reading Habits Tool. The reliability coefficient obtained through Cronbach's Alpha was 0.84 .

The intrinsic validity of the test is 0.87 which determines that the tool was highly valid. 


\section{ANALYSIS AND INTERPRETATION}

Hypothesis - 1: There exists no significant difference in the reading habits among student teachers in relation to their age.

Table 1: Showing student teachers reading habits age

\begin{tabular}{|c|c|c|c|c|c|c|c|}
\hline & Age & N & Mean & SD & F & Sig. & Df \\
\cline { 2 - 7 } Reading Habits & $18-25$ Years & 446 & 173.18 & 30.53 & & & \\
\cline { 2 - 7 } & $26-30$ Years & 108 & 170.51 & 30.97 & \multirow{4}{*}{.570} & \multirow{3}{*}{.566} & \multirow{3}{*}{2,597} \\
\cline { 2 - 7 } & 31 Years and Above & 46 & 169.46 & 28.18 & & & \\
\cline { 2 - 6 } & Total & 600 & 172.42 & 30.41 & & & \\
\hline
\end{tabular}

From the above table, out of the total of 600 student teachers, 446 were from the age group of 18 - 25 years, 108 were from the age group of 26 - 30 years and the remaining 46 were from the age group of 31 years and above. The mean score obtained for student teachers with the age group of 18 to 25 years was 173.18, for the student teachers with the age group of 26 to 30 years was 170.51 and for the student teachers with the age group of 31 years and above was 169.46. The obtained F value .570 with a df of 2 and 597 was found to be statistically not significant.

It may be observed from the mean score that, student teachers with the age group of 18 to 25 years were better than student teachers with the age group of 26 to 30 years who in turn were better than the student teachers with the age group of 31years and above in Reading habits. It was clear from the above table that $\mathrm{F}$ Ratio for student teachers with reading habits came out to be .570 , which was statistically not significant.

Hence the hypothesis 1, which states that 'There exists no significant difference in the reading habits among Student Teachers in relation to their age', is accepted.

Hypothesis - 2: There exists no significant difference in the reading habits among student teachers in relation to their gender.

Table 2: Showing student teachers reading habits gender

\begin{tabular}{|c|c|c|c|c|c|c|c|}
\hline \multirow{3}{*}{ Reading Habits } & Gender & N & Mean & SD & t & Sig. & Df \\
\cline { 2 - 8 } & Male & 300 & 169.28 & 24.41 & & & \\
\cline { 2 - 7 } & Female & 300 & 175.55 & 35.18 & 2.536 & \multirow{3}{*}{.01} & \multirow{3}{*}{1,598} \\
\cline { 2 - 7 } & Total & 600 & 172.42 & 30.41 & & & \\
\hline
\end{tabular}

From the above table, out of the total of 600 student Teachers, 300 were boys and the remaining 300 were girls. It is evident from the above table that $50 \%$ of the student Teachers were boys and $50 \%$ were girls. The standard deviation was found to be 24.41 for male student teachers while for female student teachers was 35.18. The mean score obtained for male student teachers was 169.28 and female student teachers were 175.55. The obtained t value 2.536 with a df of 1 and 598 was found to be statistically highly significant at .01 level of significance. It was clear from the above table that $t$ value for student teachers with reading habits came out to be 2.536, which was highly significant at .01 level of significance.

(c) The International Journal of Indian Psychology, ISSN 2348-5396 (e)| ISSN: 2349-3429 (p) | 173 
Therefore, it may be inferred that, female student teachers were better than male student teachers in reading habits and it was statistically significant.

Hence the hypothesis 2, which states that 'There exists no significant difference in reading habits among student teachers in relation to their gender', is rejected.

Hypothesis - 3: There exists no significant difference in the reading habits among student teachers in relation to their management.

Table 3: Showing student teachers reading habits management

\begin{tabular}{|c|c|c|c|c|c|c|c|}
\hline \multirow{3}{*}{ Reading Habits } & Management & N & Mean & SD & t & Sig. & Df \\
\cline { 2 - 8 } & Government & 279 & 175.52 & 35.83 & & & \\
\cline { 2 - 7 } & Private & 321 & 169.72 & 24.51 & \multirow{3}{*}{2.337} & .01 & \multirow{2}{*}{1,598} \\
\cline { 2 - 7 } & Total & 600 & 172.42 & 30.41 & & & \\
\hline
\end{tabular}

From the above table, out of the total of 600 student teachers, 279 were from government management and the remaining 321 were from private management. It is evident from the above table that $53.5 \%$ of the student teachers were from private colleges and $46.5 \%$ were from government colleges. The mean score obtained for government student teachers was 175.52 and private student teachers were 169.72. The obtained t value 2.337 with a df of 1 and 598 was found to be statistically highly significant at .01 level of significance.

Therefore it may be inferred that government student teachers were better than private student teachers in reading habits and it was statistically significant.

It is clear from the above table that $\mathrm{t}$ value for student teachers with reading habits came out to be 2.337, which was statically highly significant at .01 level of significance.

Hence the hypothesis 3, which states that 'There exists no significant difference in the reading habits among student teachers in relation to their management', is rejected.

\section{FINDINGS}

1. Student teachers with the age group of 18 to 25 years were better than student teachers with the age group of 26 to 30 years who in turn were better than the student teachers with the age group of 31years and above in Reading habits.

2. Female student teachers were better than male student teachers in reading habits.

3. Government student teachers were better than private student teachers in reading habits.

\section{CONCLUSION}

The present study focused on the reading habits of student teachers in relation to their age, gender and management. It was found that there was a significant difference between the reading

(C) The International Journal of Indian Psychology, ISSN 2348-5396 (e)| ISSN: 2349-3429 (p) | 174 


\section{Reading Habits among Student Teachers In Relation To Their Age, Gender and Management}

habits of student teachers. The government were found to have significantly better study habits than that of private institutes. Female student teachers were better than male student teachers in reading habits. The result reveals that there was a significant difference in Reading Habits among student teachers with respect to age, gender and management

\section{Acknowledgments}

The author appreciates all those who participated in the study and helped to facilitate the research process.

\section{Conflict of Interests}

The author declared no conflict of interests.

\section{REFERENCES}

Chauhan, P., \& Lal, P. (2012). Impact of Information Technology on Reading habits of College Students. International Journal of Research Review in Engineering Science and Technology. http://ijrrest.org/issues/?page_id=1

Dadzie, P. S. (2008) Reading for Education: The roles of Libraries. Ghana Library Journal, Vol. 20. No. 1. pp. 1-14

Deavers, R. (2000) The Effect of Instruction on Early Non-Word Reading Strategies. Journal of Research in Reading.No.23, pp 267-286.

Gallo, D. (2007) Reading Interests and Habits of Connecticut Students in Grades Four through Twelve. The Reading Matrix. Vol. 2, No.3 pp 1-20.

Gambrell, L.B., Palmer, B.M., Codling, R.M., \& Mazzoni, S.A. (1996). Assessing motivation to read. The Reading Teacher, 49, 518-533.

Greene, B. (2001) “Testing Reading Comprehension of Theoretical Discourse with Close” Journal of Research in Reading. 24 (1) pp. 32-98

Loan, F. A. (2009). Impact of New Technology on Reading Habits: A Glimpse on the World Literature.

M.C. and D.J. Kear. (1990). Measuring attitude toward reading: A new tool for teachers. The Reading Teacher 43, 626-639.

Nolen, S. B. (2007). Young children's motivation to read and write: Development in social contexts. Cognition and Instruction. 25, 219-270.

Noor, N. M. (2011). Reading Habits and Preferences of EFL Post Graduates: A Case Study, Indonesian

Ogbodo, R.O. (2010) Effective Study Habits in Educational Sector: Counseling Implications. Edn Journal of Counseling, Vol. 3, No.2. pp. 1-11

Palani, K. K. (2012) Promising Reading Habits and Creating Literate Social. International Reference Research Journal Vol. III Issue 2(1) pp 91.

Singh, Y. G. (2011) Academic Achievement and Study Habits of Higher Secondary Students. International Referred Research Journal3 (27) pp. 2

(C) The International Journal of Indian Psychology, ISSN 2348-5396 (e)| ISSN: 2349-3429 (p) | 175 
Reading Habits among Student Teachers In Relation To Their Age, Gender and Management

Thurrott, P. (2011). Better Reading Through Technology. Retrieved on October 14, 2013 from:http://winsupersite.com/article/mobile-computing-devices/reading-technology136102

How to cite this article: R Babu, P Durgaiah (2016), Reading Habits among Student Teachers In Relation To Their Age, Gender and Management, International Journal of Indian Psychology, Volume 3, Issue 4, No. 65, ISSN 2348-5396 (e), ISSN: 2349-3429 (p), DIP:18.01.149/20160304, ISBN: 978-1-365-34680-4 